\title{
Digital quality: from necessity to opportunity
}

\author{
Ludmila Shcherbakova, Ludmila Zobova*, and Elena Evdokimova \\ Kemerovo State University, Kemerovo, Russia
}

\begin{abstract}
The article substantiates the systemic quality of digital society as an internal need for digital equality. The basis of the proof is the analysis of new properties of modern information: accessibility (spatial distribution and affordability) and dynamism (increase of its quantity and quality). It is shown that systematic quality is implemented through the productiontechnical and institutional-economic relations of the digital society thanks to the technologies of the second wave of the digital revolution: open information systems, a comprehensive Internet and big data, cloud technologies and social networks. The article presents the mechanisms changing under the influence of the system quality of the digital society: ensuring management at all levels, forming an optimal sectoral structure, identifying new sources of economic growth, changing the role of an individual in solving the problem of social development. The article summarizes that models, tasks and forms of realization of modern digital policy depend on the degree of implementation of the system quality, i.e. equality.
\end{abstract}

\section{Introduction}

One of the features of the development of digital economy is the recognition of the fact of simultaneous manifestation of two opposing trends: the narrowing and expansion of the inequality of digital spatial [1]. For the global world, it is fundamentally important to answer the question of the possible achievability of digital spatial alignment and the consequences of failure or partial success for global actors.

There is a point of view that digital equality has either already been overcome or significantly reduced [2]. Moreover, the further assistance to developing countries to develop digital technologies is under question [3]. In real life, digital equality is currently a kind of "mirage". It is necessary to analyze the digital aspects of political, social, cultural, economic dimensions so that inequality does not increase with the help of digital technologies [4].

The goal of the research: to clarify the term "digital spatial equality/inequality"; to justify the necessity to achieve the greatest possible spatial digital equality in the global world.

\section{Study methodology}

To achieve this goal, there is a need for an adequate research methodology. Theoretical approaches to the analysis of categories "digital equality/inequality" are laid down in the

\footnotetext{
* Corresponding author: $\underline{1 \mathrm{zob} @ \text { mail.ru }}$
} 
works of M. Castels (2000) and Arrow (1995) [5, 6]. Over the past decades, the digital inequality has reached significant proportions, the analysis of which has been reflected in numerous studies. The works of Janvan Dijk show the depth of digital inequality in the global economy [7]. The further research gave the opportunity to formulate the problem of qualitative and quantitative manifestation of digital equality/inequality on the basis of the conclusions of Cobb-Douglass [8].

\section{Results of the study}

For its successful formation and development, digital society needs a relationship of digital equality. Digital inequality is a barrier to the digital society and economy, while digital equality is suitable to its essence [9]. The problem of information equality/inequality in the new economy is not limited to indicators of accessibility of even the use of digital technologies. It has a deeper meaning since digital equality is a systematic property of the information society, i.e. a new systematic quality of socio-economic relations is formed.

Digital equality/inequality manifests itself on the basis of the criterion of accessibility. Accessibility comes in two directions: spatial accessibility and cost accessibility. Spatial accessibility means that information resources, being virtual and intangible, easily cross national borders, i.e. they have a global (cross-border) character. The idea of close interaction, the merging of globalization, and informatization was reflected in the works of M. Castells [5]. Cost accessibility, i.e. the attraction to the free use is carried out through the offer of a sufficiently large amount of free information. Secondly, goods and services of information production are an example of not only positive but also negative cost dynamics. The trend of falling prices remained and, at the same time, it equally affected both developed and developing countries [2].

Universality, social belonging as a systemic property of information should change the nature of the functioning of many mechanisms of the system. The need for digital equality is explained by acceleration and increase of amount of information; the need for expansion of access, equal accessibility to the benefits of digital economy: to office equipment, information databases, information services [10].

Changes in the quantity and quality of information and its increased availability are the basis for a new quality of management, regulation of society, and the economy. The content of managements also changes in digital society, instead of being product oriented, it becomes a management function. The degree of digital equality in a new society defines whether the new quality of management will be provided.

The quantitative growth of information, the rapid increase in the totality of knowledge and information can cause social imbalance, loss of manageability. It is natural to believe that digital revolution that has led to a new systemic quality, has caused both the need for a new level of regulation and its possibility. This need is predetermined by the dynamics of information flows, the growth of the amount of information and its new quality. The possibility of new level of management is also connected with the growth of the amount of information, as well as with the equal access to information. As the result, there is need for equality in the provision of digital technology, equal access to information databases and the provision of services of the sector of Internet. There is an opportunity of a qualitatively new level of management.

Thus, digital spatial equality is a quality of a globalized information society that manifests in spatial and cost accessibility of information flows and services of information sector. 


\section{Discussion of results}

The existing indicators of the development of information society show that the dynamics of increase of digital technologies in countries with a low level of development is higher that in the developed countries (we are talking about the last decade). First of all, there was a sharp increase in the growth rates of access to mobile communications and the number of Internet users all over the world. Manufacturing companies of the corresponding profile set the goal of providing mobile communication to $50 \%$ of the world's population by 2015 , the task was completed earlier, currently the level of mobile communication coverage is close to $95 \%$ [2]. (Table 1).

Table 1. Dynamics of the number of Internet users for the period 2000-2019, regions of the world.

\begin{tabular}{|c|c|c|c|c|}
\hline $\begin{array}{c}\text { Region of the } \\
\text { world }\end{array}$ & $\begin{array}{c}\text { Population, } \\
\mathbf{2 0 1 9} \text { (ths.) }\end{array}$ & $\begin{array}{c}\text { Number of } \\
\text { Internet users, } \\
\text { March 2019, } \\
\text { (ths.) }\end{array}$ & $\begin{array}{c}\text { Internet } \\
\text { connectivity, } \\
\text { in \% to } \\
\text { population }\end{array}$ & $\begin{array}{c}\text { Growth rates of } \\
\text { Internet users } \\
\text { for the period } \\
\mathbf{2 0 0 0 - 2 0 1 9 ,} \text { in } \\
\text { \% }\end{array}$ \\
\hline Africa & 1320038716 & 492762185 & 37.3 & $11.2 \%$ \\
\hline Asia & 4241972790 & 2197444783 & 51.8 & $50.1 \%$ \\
\hline Europe & 829173007 & 719365521 & 86.8 & $16.4 \%$ \\
\hline Middle East & 258356867 & 173542069 & 67.2 & $4.0 \%$ \\
\hline North America & 366496802 & 327568127 & 89.4 & $7.5 \%$ \\
\hline $\begin{array}{c}\text { Latin/Caribbean } \\
\text { America }\end{array}$ & 658345826 & 444493379 & 67.5 & $10.1 \%$ \\
\hline Oceania/Australia & 41839201 & 28634278 & 68.4 & $0.7 \%$ \\
\hline World & 7716223209 & 4383810342 & 56.8 & $100 \%$ \\
\hline
\end{tabular}

Compiled according to: [11].

It is safe to note the trend towards more active infusion of less developed countries into the information economy. There are several reasons for this trend. Firstly, the developed countries have been leading for quite a long time both in the industries producing information technology in the use of Internet and in the development of mobile communications, i.e. they have entered a period of certain saturation with the benefits of the digital revolution. Secondly, the achieved results of information equalization in the global economy are largely the merit of world institutions. In the beginning, the formation of information society occured on the basis of the idea of importance of equality in the use of digital technologies, there was an opinion that the narrowing of digital inequality is necessary for education and economic stability [3]. To solve this problem, measures were proposed to ensure universal access to digital technologies: control over market conditions in the sale of information services; expansion of public access to information technology through open access enterprises; assistance to people with disabilities in introducing new innovative digital technologies [12].

Further, a range of other institutes was created: funds, initiatives aimed at digital equalization: United Digital Assistance Fund; Fund 50*15; One laptop per child; Equal Access to Software and Information, etc. The search for ways to narrow digital inequality showed that this task should be solved in a comprehensive manner, using educational, technical, and cultural means [7].

The need for digital equality, equal accessibility of information benefits finds its expression in production-technical and institutional and economic relations of digital society. The importance of open systems is growing. In the last decade, the Comprehensive Internet based on bid data has been spreading, cloud technologies and social networks have been functioning. 
The specificity of the modern period is that an increasing number of scientists and practitioners are becoming supporters of open data. Open Data Councils that include representatives of various fields of activity: management, information sector, expert teams, have received a large scale of distribution. Open data is given a role of a tool that eliminates discrimination on access to information and ensures dynamic development [13].

Big Data is a technical instrument that reflects the need of the society for digital equality since each subject of society can contribute to building up the benefits of Big Data; the more participants of digital exchange are, the more perfect the mechanism of work of Big Data $[14,15]$.

The logic of the use of cloud technology is special, the storage of information in clouds makes it almost useless to control the data at the micro-level.

Social networks as a technology initially serve as a common space for functioning of separate subjects. When analyzing the results of the network, the emphasis is not on the role of individual structural units, but on the connections, relationships between them. The behavioral strategy of its participants depends not on their own desires and preferences, but on the nature and structure of the network. Within the framework of the institutional analysis of social networks, it is quite natural to conclude that stable network interactions of its participants are associated with positive externalities. It means that the results of the work of the network affect third parties that have benefits in the form of basic information flows and access to the necessary service and product providers.

In digital society there is an opportunity for new quality of regulation. Digital resource, unlike information resources of previous periods, has a distinctive feature an innovative good associated with scientific progress. Modern digital technologies that provide a new quality of processing, preservation and transmission of information, make it possible to collect and analyze data, develop managerial decisions, transfer the decisions to the lower levels in the form of information flows faster and more efficiently.

However, management of modern business processes should follow the rule of coordination and synchronization of actions, coordination of strategies. This mechanism is possible when each subject of information relations has equal access to management resources.

Information resources increase the quality of management at the macro level and global level, of course, taking into account certain specifics. At the macro level, digital revolution in management has created an opportunity to eliminate middle management, in fact, this is the second revolution in the field of management. Moreover, public administration based on digital technology is becoming an "electronic government", which can potentially become a new stage of economical and reasonable management of the economy.

Digital technologies have the potential to completely change the system of governance in the entire global world. The global society is faced with serious challenges that consist in the need to solve ecological problems, overcome socio-economic differentiation, respond to the special nature of cyclical fluctuations in the economy. The new quality of management provided by the development of digital technologies can contribute to this.

The need for digital equality manifests itself in the structural transformations of social production. Firstly, it is caused by emergence of new spheres of business, particularly, by development of electronic business, electronic commerce, electronic governance, wide-range mobile Internet, branches that produce information technology. At the same time, there is a problem of employment of other people [16].

Formation of a new system of values is one of the most important features of a new information society [17]. Unfortunately, the new opportunities of digital technologies were used not so much by the creative class as by the bureaucratic stratum of society for their own selfish interests. The speed of transfer of information revealed for it the opportunity to increase the number of instructions, commands, verifications and, as a result, to expand the 
class of bureaucracy. In general, in economy, the advantages of digital economy, first of all, were beneficial for financial and advertising sector, they caused a powerful surge in fraudulent transactions in cyberspace.

Digital equality of society implies an increase in the productivity of public labor. This statement is controversial. However, already at the first stage of the information revolution, the appearance of computers showed the effect of saving electricity, reducing the cost of information processing, by increasing the speed of transmission of information as well. (Table 2).

Table 2. The rating of countries by labor productivity, competitiveness and science expenditures, 2019.

\begin{tabular}{|c|c|c|c|c|}
\hline Country & $\begin{array}{c}\text { Labor productivity in } \\
\text { innovative economy, } \\
\text { (place in the world) }\end{array}$ & $\begin{array}{c}\text { Competitivenes } \\
\text { s in digital } \\
\text { environment, } \\
\text { (place in the } \\
\text { world) }\end{array}$ & $\begin{array}{c}\text { Science } \\
\text { expenditures } \\
\text { (\% of GDP), } \\
\text { (place in the } \\
\text { world) }\end{array}$ & $\begin{array}{c}\text { Working time } \\
\text { required to buy } \\
\text { an iPhone } \\
\text { (hours) }\end{array}$ \\
\hline $\begin{array}{c}\text { Republic } \\
\text { of Korea }\end{array}$ & 29 & 14 & 1 & 56 \\
\hline Japan & 35 & 22 & 5 & 35 \\
\hline USA & 12 & 3 & 8 & 27.5 \\
\hline China & 47 & 30 & 10 & 142 \\
\hline Russia & 43 & 40 & 18 & 119 \\
\hline India & 59 & 48 & 20 & 369.4 \\
\hline
\end{tabular}

Compiled according to: $[18,19]$

The remaining inequality in labor productivity in the countries of the world also predetermines digital spatial inequality. Thus, working time required to buy an iPhone in North America is 35 hours, in Western Europe - 48 hours, in Eastern Europe, South America, Asia and Africa it will require more than three weeks of work on average. [20]

There were attempts to mathematically calculate the magnitude of the impact of digital technologies on labor productivity; for this purpose, the Cobb-Douglas function was used. The Cobb-Douglas function formula for determining the impact of the digital resource on economic growth is as follows:

$$
V(t)=A \cdot K(t)^{p} L(t)^{q}, P+Q=1,
$$

where $\mathrm{V}(\mathrm{t})$ - annual output;

$\mathrm{K}(\mathrm{t})$ - capital (for one year);

$\mathrm{L}(\mathrm{t})$ - number of the employed (for one year);

A, $p, q$ - variables, estimated parameters.

It would be logical to include in the Cobb-Douglas function the factor of digital inequality-equality by taking it into account in the coefficients of elasticity of capital and labor ( $\mathrm{P}$ - capital elasticity, share of capital contribution to GDP and q - labor elasticity, share of labor contribution to GDP), so as the above ratios should reflect the degree of management efficiency.

The role of the individual consumer in the system-forming property of the digital society, the need for digital equality, should be noted. The household as a subject has received enormous opportunities in the implementation of its functions with the emergence of new technologies. With their help, online access to knowledge, web-based training, cultural objects is provided, the consumer can buy goods at home using e-commerce tools, can give feedback and exchange information with sellers and other consumers. 


\section{Conclusion}

The conducted research allows to conclude that the systemic quality of the digital society is the internal need for digital equality based on two properties of information: availability and growth of its quantity and quality.

1) Digital equality is implemented with the help of production-technical and institutional and economic relations of digital economy, which is facilitated by new generation technologies: open information systems; Comprehensive Internet with bag data; cloud technologies and social networks;

2) Universality as a systemic feature of digital society changes the nature of functioning of many mechanisms of the system: the quality of public administration, the formation of an optimal sectoral structure, the search for new sources of economic growth, the importance of an individual in solving the problem of social development;

3) Disunity of interests of the modern market economy prevents the deployment of digital equality access to all advantages of digital society that manifests itself in information wars, loss of information security, digital inequality, excessive expansion of certain sectors of the economy;

4) Modern digital policy in its direction and implementation mechanisms should take into account the presence of reasons that hinder the formation of a full-fledged digital economy and society, the need to overcome them. The content of digital economy should be defined by the choice of a certain model of digital society that can be focused on the deployment of its systemic quality (i.e. equality) or, on the contrary, hinder its formation.

\section{References}

1. V.A. Shabashev, L.N. Shcherbakova, Sociological Research 9, 3 (2016)

2. Measuring the Information Society Report 2018, Geneva: Internatinal

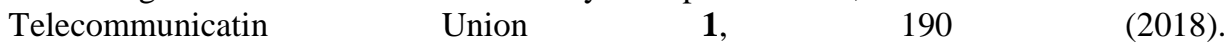
https://www.itu.int/en/ITUD/Statistics/Pages/publications/misr2018.aspx

3. J. Moore, Equity, Technology and Narrowing The Digital Divide (2014). https://div46amplifier.com/2014/05/16/equity-technology-and-narrowing-the-digitaldivide/

4. What is digital equality? An interview with Nanjira Sambuli (2019). https://www.weforum.org/agenda/2019/04/digital-equality-interview-nanjira-sambuli/

5. M. Castells, The Information Age: Economy, Society and Culture, (Moscow: SU HSE, 2000)

6. K. Arrow, Economic Issues 5, 98 (1995).

7. J. A. G. M. VanDijk, The digital divide, Cambridge, England: Polity (2020)

8. D. Renshaw, Mathematics for Economics, 516 (New York, Oxford University Press, 2006)

9. L.N. Shcherbakova, L.L. Zobova, E.K. Evdokimova, L.V. Kusurgasheva, Object and Principles of Digital Policy Implementation, Advances in Economics, Business and Management Research 148, 172 (2020). DOI: 10.2991 / aebmr.k.200730.032

10. A.V. Shkalenko, The Impact Factors of the Fourth Industrial Revolution on the Current Social Development, Advances in Economics, Business and Management Research 156, 213 (2020) DOI: 10.2991/aebmr.k.201205.035

11. The Internet Big Picture. World and 2019 Population Stats Internet Users, Miniwatts Marketing Group (2019). https://www.internetworldstats.com/stats.htm 
12. Okinawa Charter for the Global Information Society, Japanese Ministry of Foreign Affairs. http://www.mofa.go.jp/policy/economy/summit/2000/documents/harter.html

13. M. Raunio, Forsyth 12(2), 62 (2018)

14. M. Florio, E. Sirtori, Technological Forecasting and Social Change 65, 112 (2015) DOI: $10.1016 /$ j.techfore.2015.11.024

15. S. Lynch, Nature 455, 28 (2008) DOI: 10.1038 / 455028a

16. E. Hines, Forsyth 13(1), 19 (2019)

17. L. Zobova, L. Shcherbakova, E. Evdokimova, S. Savintseva, Features of information technologies influence on social development, Advances in Social Science, Education and Humanities Research 198, 70 (2018). DOI: 10.2991 / ictppfms-18.2018.13

18. Ranking of countries in terms of spending on science. https://zen.yandex.ru/media/show_me_world/reiting-stran-po-zatratam-na-nauku-vprocentah-ot-vvp-5e3d6c903aa8ed76a4778ca7

19. Rating of innovative economies - 2020: Germany came out on top https://theworldonly.org/rejting-innovatsionnyh-ekonomik-2020/

20. A comparison of purchasing power around the globe. http://81.47.175.201/ETMS/rankings/2012_UBS_Prices_earnings.pdf 